\title{
Human milk: processing and conservation - a review
}

\author{
Leite humano: processamento e conservação - uma revisão \\ Leche materna: procesamiento y conservación: una revisión
}

Received: 09/01/2021 | Reviewed: 09/08/2021 | Accept: 09/13/2021 | Published: 09/14/2021

\author{
Matheus Campos Castro \\ ORCID: https://orcid.org/0000-0002-9918-1491 \\ State University of Maringá, Brazil \\ E-mail: 1996mcastro@gmail.com \\ Eloize Silva Alves \\ ORCID: https://orcid.org/0000-0002-3340-8374 \\ State University of Maringá, Brazil \\ E-mail: eloizeetaus@gmail.com \\ Bruno Henrique Figueiredo Saqueti \\ ORCID: https://orcid.org/0000-0002-1118-4605 \\ State University of Maringá, Brazil \\ E-mail: bruno_saqueti@outlook.com \\ Patrícia Magalhães Souza \\ ORCID: https://orcid.org/0000-0001-5916-0744 \\ State University of Maringá, Brazil \\ E-mail: patrícia.magalhaes11@hotmail.com \\ Luciana Pelissari Manin \\ ORCID: https://orcid.org/0000-0002-5429-5743 \\ State University of Maringá, Brazil \\ E-mail: lucianapmanin@hotmail.com \\ Roberta da Silveira \\ ORCID: https://orcid.org/0000-0002-0037-4307 \\ State University of Maringá, Brazil \\ E-mail: dasilveira.roberta@gmail.com \\ Grasiele Scaramal Madrona \\ ORCID: https://orcid.org/0000-0003-1204-525X \\ State University of Maringá, Brazil \\ E-mail: gsmadrona@uem.br \\ Oscar de Oliveira Santos \\ ORCID: https://orcid.org/0000-0002-9631-8480 \\ State University of Maringá, Brazil \\ E-mail: oliveirasantos.oscardeoliveira@gmail.com \\ Jesuí Vergílio Visentainer \\ ORCID: https://orcid.org/0000-0003-3412-897X \\ State University of Maringá, Brazil \\ E-mail: jesuivv@gmail.com
}

\begin{abstract}
Human milk has a balance of nutrients and bioactive compounds, and it must be the exclusive food source during the first six months of the infant's life. In cases where the woman is unable to breastfeed, due to hypogalactia or preexisting disease, the use of donated human milk, available in human milk banks, is recommended. Currently, in the human milk banks the processing applied for greater conservation is Holder pasteurization. Therefore, the objective of this work is to perform a search in the literature about new possible treatments to be applied to human milk, and its influence on its physical-chemical composition; and in this sense, the studied processes were: Holder pasteurization, lyophilization, spray-drying, high hydrostatic pressure, high temperature and short time, and short wave ultraviolet irradiation. For that, a search was performed in databases, and 126 articles were selected to carry out this review according to the keywords used. It was observed that the studied treatments can be applied for the processing and conservation of human milk, once it was applied in matrices with similar composition.
\end{abstract}

Keywords: Holder pasteurization; Lyophilization; Spray-drying; High hydrostatic pressure; High temperature and short time; Ultravioleta irradiation.

\section{Resumo}

O leite humano possui um equilíbrio de nutrientes e compostos bioativos, e deve ser a fonte alimentar exclusiva durante os primeiros seis meses de vida da criança. Nos casos em que a mulher não consegue amamentar, por hipogalactia ou doença preexistente, é recomendado o uso de leite humano doado, disponível em bancos de leite humano. Atualmente, nos bancos de leite humano o processamento aplicado para maior conservação é a pasteurização 
Holder. Portanto, o objetivo deste trabalho é realizar um levantamento na literatura sobre novos possíveis tratamentos a serem aplicados ao leite humano, e sua influência na sua composição físico-química; e, nesse sentido, os processos estudados foram: Pasteurização de suporte, liofilização, spray-drying, alta pressão hidrostática, alta temperatura e curto tempo, e irradiação ultravioleta de onda curta. Para tanto, foi realizada uma busca nas bases de dados, sendo selecionados 126 artigos para a realização desta revisão de acordo com as palavras-chave utilizadas. Observou-se que os tratamentos estudados podem ser aplicados para o processamento e conservação do leite humano, uma vez que foi aplicado em matrizes com composição semelhante.

Palavras-chave: Pasteurização do suporte; Liofilização; Secagem por pulverização; Alta pressão hidrostática; Alta temperatura e curto espaço de tempo; Irradiação ultravioleta.

\section{Resumen}

La leche materna tiene un equilibrio de nutrientes y compuestos bioactivos, y debe ser la fuente de alimento exclusiva durante los primeros seis meses de vida del bebé. En los casos en que la mujer no pueda amamantar, debido a hipogalactia o enfermedad preexistente, se recomienda el uso de leche materna donada, disponible en los bancos de leche materna. Actualmente, en los bancos de leche materna el procesamiento aplicado para mayor conservación es la pasteurización Holder. Por tanto, el objetivo de este trabajo es realizar una búsqueda en la literatura sobre nuevos posibles tratamientos a aplicar a la leche materna, y su influencia en su composición físico-química; y en este sentido, los procesos estudiados fueron: pasteurización en soporte, liofilización, secado por aspersión, alta presión hidrostática, alta temperatura y corto tiempo, e irradiación ultravioleta de onda corta. Para ello se realizó una búsqueda en bases de datos y se seleccionaron 126 artículos para realizar esta revisión según las palabras clave utilizadas. Se observó que los tratamientos estudiados se pueden aplicar para el procesamiento y conservación de la leche materna, una vez aplicada en matrices de similar composición.

Palabras clave: Pasteurización del titular; Liofilización; Secado por atomización; Alta presión hidrostática; Alta temperatura y poco tiempo; Irradiación ultravioleta.

\section{Introduction}

Human milk must be an exclusive source during the first semester of newborns' life (Johnston, Landers, Noble, Szucs, \& Viehmann, 2012; Eidelman, \& Schanler, 2012) and offered up to 2 years of age with complementary feeding. If breastfeeding is interrupted, due to hypogalactia, pre-existing diseases, or other factors, the availability of donations in human milk banks is necessary. Human milk banks are responsible for the collection, processing, quality control and distribution, guaranteeing a safe product and free from pathogenic microorganisms (Brasil, 2008; Akinbi et al., 2010). The quality of this milk received (donated) to milk banks is the result of hygienic conditions from milking to administration (Brasil, 2008; Borges, Oliveira, Hattori, \& Abdallah, 2018).

In Brazillian human milk banks, milk that does not reach certain specifications must be disposed directly in the sewage system without prior treatment, as provided in RDC/Anvisa $n^{\circ}$ 306/2004 (Brasil, 2004; Brasil, 2006). Grazziotin, Grazziotin, and Letti (2010) reports a volume of human milk disposal from $10.5 \%$ to $24 \%$ of the total received, with mature milk (more than 15 days postpartum) with greater volume collected and discarded in their research. Human milk banks are responsible for the collection, processing, quality control and distribution in cases of interruption of breastfeeding (Brasil, 2008; Akinbi et al., 2010).

There are processes that guarantee greater conservation and microbiological safety of human milk, namely: Holder pasteurization and lyophilization (Castro et al., 2017; Visentainer et al., 2018). Among its principles, Holder pasteurization is considered a standard treatment in human milk banks, performed at a temperature of $62.5^{\circ} \mathrm{C}$ for a period of 30 minutes (Peixoto et al., 2020). The lyophilization technique is performed after pasteurization, the milk is frozen at $-18{ }^{\circ} \mathrm{C}$ and then the drying takes place in two stages by removing the water by sublimation followed by desorption through the material frozen under vacuum; generating benefits such as longer conservation time and less storage space (Picaud, \& Buffin, 2017).

Currently, new methods are being investigated, such as the spray-drying technique (Cavazos-Garduño et al., 2016) and high pressure processing (Demazeau, 2015; Mayayo et al., 2014). The spray-drying treatment can be an alternative, since it is widely used industrially for the production of powdered bovine milk (Malafronte, Ahrné, Innings, Jongsma, \& Rasmuson, 
2015). In this process the milk is sprayed in droplets inside a drying tower, and the product comes into contact with the heated air (Silva et al., 2017; Mujumdar, Huang, \& Chen, 2010).

High pressure processing has been used to inactivate pathogenic microorganisms in solid and liquid foods (MateosVivas et al., 2015). This technology applies high pressure (400 to $800 \mathrm{MPa}$ ) for a short period of time. Both techniques have already been tested in human milk in hydrostatic way, with positive results in relation to quality and conservation (Huppertz, Fox, de Kruif, \& Kelly, 2006; Delgado, Cava, Delgado, \& Ramírez, 2014). Other techniques have also been studied, such as, high temperature and short time (HTST), and short wave ultraviolet irradiation. With this, the present study aims to bring a review of all the techniques mentioned for the processing of human milk.

\section{Methodology}

Searches were performed in the Google Scholar, Scielo and Science direct databases with keywords for data search: Human milk, Holder Pasteurization; Lyophilization; Spray-drying; high hydrostatic pressure; high temperature and short time; ultravioleta irradiation. Thus, being a qualitative methodological search in a literature review (Pereira, Shitsuka, Pereira, \& Shitsuka, 2018).

\section{Results and Discussion}

\subsection{Human milk - main characteristics and composition}

Human milk is considered the standard food for newborn, recommended by regulations as exclusive source of nutrition during the first six months of life (Johnston, Landers, Noble, Szucs, \& Viehmann, 2012), it is able to supply nutrients and bioactive compounds, establishing a qualitative and quantitative balance between it, which benefit in maturation, development and protection against diseases (Dórea, Fenton, LaKind, \& Berlin, 2012) for containing immunological properties (Briere et al., 2016).

The human milk composition consists of approximately $90 \%$ of water, 6-7\% of lactose, 3.2-3.6\% of lipids and 0.9$1.2 \%$ of proteins, with lipids providing half of the total human milk energy and facilitate the transport and absorption of fatsoluble vitamins for the infant (Ballard, \& Morrow, 2013; Silva, 2007). In comparison, the bovine milk composition is $89 \%$ water, 4.21\% lactose, 3.48\% lipids and 3.29\% proteins (De Andrade, 2014; Silveira, Fonseca, Cançado, \& Ferraz, 2004).

Human milk has unparalleled and irreproducible characteristics, for example, milk from other species, such as, bovine milk or infant formulations does not have the growth and immunological factors, specific hormones and types of fat globules that human milk has (Picciano, 1998).

One of the ways used to characterize human milk is to consider the postpartum period, being 0-7 days called colostrum, 8-14 days considered as transition milk and after the 15th day considered as mature milk (Ballard, \& Morrow, 2013). Its composition is variable according to the different lactation stages, gestational age, maternal diet, breastfeeding time, offspring, in addition to the time of breastfeeding, which is also a determining factor (Sinanouglou et al., 2017).

\subsection{Human milk banks}

Human milk banks were created in Brazil for cases in which breastfeeding is interrupted or prevented, and also to guarantee the human milk quality; they are responsible for encouraging breastfeeding, providing guidance on the practice of breastfeeding, collection for donation, application of processing (pasteurization or pasteurization+freeze-drying), as well as its distribution (Maia, Almeida, Novak, \& Silva, 2006). In a study carried out at an accredited human milk bank, the Brazilian Network of Human Milk Banks, it is reported that it has functions to encourage home milking, ensures donor guidance, 
performs systematic evaluation and home visit, and has its own car and trained employees for the safe transport of human milk (Borges, Oliveira, Hattori, \& Abdallah, 2018).

Studies have been carried out to determine whether the cooling time can be extended, greater than the current 6 months. This period is not extended due to the concern of contamination and reductions in properties (Kumar, 2017). Unpasteurized human milk has bactericidal properties. This activity remains unchanged during the first 72 hours of cold storage, but is later lost (Fugate, Hernandez, Ashmeade, Miladinovic, \& Spatz, 2015).

In human milk banks, the thermal process used is Holder pasteurization, a process that allows the application of temperature for a certain time, effective against microbiological contamination (Path, 2013). The human milk received undergoes several tests in order to certify its quality, however according to the Brazilian Network of Milk Bank in 2019, 30\% of the human milk received was discarded, for reasons of high acidity, for do not meet microbiological standards, or because it contains some dirt. According to Passarini et al. (2017) in a survey carried out in 2016 in Araçatuba - São Paulo, from the total of 363.7 liters of human milk collected, 47 liters were discarded. This disposal rate may be related to improper handling during milking or storage. A major concern of human milk banks is to maintain sufficient milk stocks, and one way to achieve this goal is by decreasing the volume discarded after quality analyzes (Mitsue, 2010). A similar situation can be observed in other countries, the work of Katke, Walinjkar, Saraogi, and Tawre (2014) reports the amount of human milk received in a milk bank installed in India, from 1200 liters, 1000 liters were consumed during 2008 to 2013, the rest was considered as disposal.

Considering the absence of references about the causes of milk disposal related to donors, the work of Grazziiotin, Grazziotin, and Letti (2010) highlighted the importance of tracing human milk, in order to know and combat the reasons that result in changes in milk and optimize the use of the milk received.

According to Guimarães, Almeida, and Novak (2006), waste in milk banks is considered when the human milk is unfit for consumption. This must be subjected to treatment prior to the release in the public sewage system, as required by the competent environmental control body.

\subsection{Conservation process}

\subsubsection{Holder Pasteurization}

Reporting on human breastfeeding, a common occurrence in Neonatal Intensive Care Units is the scarcity or nonavailability of milk, thus, one of the alternatives recommended by the World Health Organization (WHO) is the donation of this fluid to the milk bank, in order to meet the needs of infants worldwide (Meneses, Oliveira, \& Boccolini, 2017). Human milk banks, in turn, have among their responsibilities the guarantee of milk quality, which is usually carried out through a process called pasteurization (Spatz et al., 2018).

Holder pasteurization, a standard process for human milk banks, is worldwide imposed, normative guidelines to be applied for sanitary reasons, it is responsible for factors such as: microbial reduction, pathogenic inactivation, preservation of the composition and increased shelf life of human milk in up to 6 months when maintained frozen after being processed (Ewaschuk, \& Urger, 2015). Ideally, the process consists of applying the sample to heat for 30 minutes in a water bath, until it reaches a temperature of $62.5^{\circ} \mathrm{C}$ in the middle of the appropriate flasks, followed by a thermal shock in water cooled to $4{ }^{\circ} \mathrm{C}$ and then the freezing close to $-18{ }^{\circ} \mathrm{C}$ (De Oliveira et al., 2016).

However, to arrive at this specification, since the most remote times, researchers have been studying, raising hypotheses, making experimental attempts, often frustrated, in order to establish the best conditions for an effective pasteurization process. In general, the processes were created first using bovine's milk and later expanded and tested for other types of milk (human, sheep, etc.). 
The first world war, in 1917, represented for industrialization, especially for the dairy industry, an important step towards accelerated development, encouraging the emergence of new industrial sectors. Since then, several new techniques have appeared on the market, and processes that were important to meet the needs of that time, many of these, were related to food, especially dairy compounds (Rankin, Bradley, Miller, \& Mildenhall, 2017).

The population began to discern that raw bovine's milk caused disease and that it was necessary to treat it before consumption, then the term "pasteurization" appeared. Despite the prominence among the local population, as it is an unknown and recently created technique, researchers performed it in secret, so as not to be the target of criticism among the scientific community (Herrington, 1948).

In the first attempt made in the United States of America, the milk was heated to a temperature of $71.1^{\circ} \mathrm{C}$, for 30 to 60 seconds, however, the researchers reported that the lactic acid bacteria present in the sample did not resist processing, with proliferation of thermorudic bacteria, which prevented the development of considerable acidity in the milk and caused it to deteriorate. Consequently, other experiments were developed varying parameters such as: time and temperature. The method called "bottle method", used a temperature of $62.8^{\circ} \mathrm{C}$ and time of 20 to 30 minutes, this showed positive results, eliminating contamination, but it did not exceed market expectations.

Several experiments were carried out, and after observing the results, it was established in the years 1890 to 1927 to develop a standard pasteurization methodology, which consisted of heating the milk at a temperature of $61.6{ }^{\circ} \mathrm{C}$ for 30 minutes (called slow pasteurization). This procedure was legalized by the first pasteurization law. Since then, there has been an exponential growth of scientists/researchers with the aim of improving pasteurization techniques for dairy compounds (Herrington, 1948).

In addition to Holder pasteurization, new techniques have been proposed, pasteurization based on solar energy, using microwave treatment, high temperature and short term application (HTST), ultrasound, high pressure processing, or irradiation ultraviolet (UV), were tested under experimental conditions (Panchal et al, 2018; Malinowska-Pańczyk et al., 2019; Giribaldi et al., 2016; Picaud, \& Buffin, 2017).

Solar energy was used to pasteurize milk residues from a farm, for this purpose, flat plates were used for heating, at different temperatures, 60, 65 and $70{ }^{\circ} \mathrm{C}$ and after some experiments it was concluded that the best condition was based on temperature of $70{ }^{\circ} \mathrm{C}$. An innovative conventional heat exchanger, also based on the use of solar energy, was developed and tested in various conditions during the year, and the results obtained for the pasteurization process showed advantages such as, greater thermal, hydraulic efficiency and increased safety, when compared to other types of pasteurization using similar technologies (Panchal et al, 2018).

Microwave pasteurization can be used as an alternative to the Holder process. Studies have shown that the microbiological quality of milk has increased, and the heat generation time was about 15 to 16 minutes shorter by applying microwaves. In addition, other positive aspects that can be considerer, for example, the inactivation of heat-sensitive bacteria at a temperature of 62 to $72{ }^{\circ} \mathrm{C}$ and the loss of the microbiota activity contained in milk, under conditions of 62.5 or $66{ }^{\circ} \mathrm{C}$ for 5 and 3 minutes, respectively (Malinowska-Pańczyk et al., 2019).

Despite the positive factors related to the studied processes, some disadvantages must be taken into account, such as the possible loss of nutritional and/or biological quality. An example is the alteration of proteins contained in milk, due to the fact that it is denatured at elevated temperature. A study by Ma, Zhang, Wu, \& Zhow (2019) reports that proteins sensitive to heat treatment, subjected to the pasteurization process, are mainly involved in lipid synthesis and secretion, as well as in the infant's immune response. Thus, it is necessary to develop future strategies in order to prevent or limit the degradation of human milk proteins. 
Another example of the loss of quality and/or nutrition is related to the wide variety of gram-positive and gramnegative bacteria, decaying bacteria and organisms found in raw milk, which cause disease. Some of these bacteria are heat resistant and able to survive the conditions of pasteurization in vegetative form, however, most of these bacteria are usually not able to survive under refrigeration, for this reason, some bacteria form spores and can be preserved in the process. A large part (approximately 50\%) of the fluid milk supply is contaminated before and after the pasteurization process, and this postcontamination limits the quality and useful life of the milk (Martin, Boor, \& Wiedmann, 2018).

Studies have reported that when it comes to Holder pasteurization, specifically, the lipid content of human milk does not change, as does its composition in fatty acids (Gao et al., 2019). This is in fact advantageous since it is the largest source of energy in human milk and lipids are essential for the infant development. Fat-soluble vitamins were also not affected by thermal processing, in contrast water-soluble vitamins and vitamin $\mathrm{C}$ underwent a significant reduction in composition. Finally, biologically active molecules, such as, cytokines and growth-modulating factors remain uncertain and enzyme activity has been reduced (Peixoto et al., 2020; Peila et al, 2016).

\subsubsection{Lyophilization}

Lyophilization is a drying method that started in 1890, applied to tissue preservation by histologist Richard Altmana and after several researches in 1920 it became conventional and applicable to several biological materials (Pisano, Arsiccio, Capozzi, \& Trout, 2019). When applied to food, lyophilization has the main objective of increasing the shelf life, avoiding the oxidation of lipids, degradation of bioactive compounds, in addition to preserving the flavor and nutritional characteristics of the food (Do Vale Morais et al., 2016). It is reported that it does not replace the pasteurization method, as it only inhibits microbial growth, pathogenic microorganisms remaining in the food matrix (Manin et al., 2019).

The lyophilization process consists of drying a frozen product using vacuum, removing water by sublimation followed by desorption (Vishali, Monisha, Sivakamasundari, \& Moses, 2019). During these steps, it is important to consider the possible physical changes caused by supercooling, changing its morphology and affecting the drying step, leading to detrimental impacts on the method performance (Assegehegn, Brito-de-la Fuente, Franco, \& Gallegos, 2019). When compared to other drying treatments, such as atomization and dehydration in the greenhouse, the lyophilization method has the disadvantage of high cost, in addition to the high consumption of energy and time (Challener, 2017).

The storage of pasteurized human milk in freezers close to $-20{ }^{\circ} \mathrm{C}$ in the milk banks can reduce its nutritional quality (Akinbi et al., 2010; Silvestre et al., 2010). Lyophilized products do not undergo changes in its composition when properly preserved, the lyophilization process causes a reduction in product volume, decreasing its storage space. The reconstitution of the product is acquired by adding water (Brasil, 2008).

Lozano, Castellote, Montes, and López-Sabater (2014) proposed a freeze-drying process in human milk in which it was frozen at $-80{ }^{\circ} \mathrm{C}$ and placed in a lyophilizer for 24 hours, with a pressure of $10^{-3}$ mbar and temperature of $-46{ }^{\circ} \mathrm{C}$, concluding that it was a good way to conserve and preserve this food, positively evaluating the stability of vitamins, fatty acids and antioxidants.

The application of the lyophilization method in milk and dairy co-products has been of great importance for the development of new technologies and new products, aiming at aspects related to quality, chemical and biochemical composition. (Vincenzetti et al., 2018; Zhu, Kebede, Chen, McComb, \& Frew, 2020). Microencapsulation techniques of microorganisms have been shown to be efficient when using freeze-drying methods, guaranteeing storage stability for increasing periods (Gan, Ong, Chin, \& Law, 2017). As well as the incorporation of probiotics in lyophilized milk matrices, made possible through the addition of disaccharides used as a cryoprotectant during the method (Basholli-Salihu et al., 2014). The freeze-drying treatment of donkey milk demonstrated that the nutritional characteristics of this product remained basically 
unchanged compared to fresh milk, being evaluated the protein composition of donkey milk, quantification of vitamin $\mathrm{C}$ and lysozyme activity (Vincenzetti et al., 2011).

The lyophilization process applied directly to human milk, has advantages in preserving important nutritional compounds for health, such as lipid composition, highlighting the conservation of alpha-linolenic fatty acids (18:3n-3), linoleic acid (18: $2 n-6)$ and its metabolites docosahexaenoic acid (22:6n-3), eicosapentaenoic acid (20: 5n-3) and arachidonic acid (20:4n-6) (Manin et al., 2019). The content of vitamin C, vitamin E and antioxidant capacity was evaluated in lyophilized human milk, obtaining satisfactory results for lyophilization in which the reduction of these compounds were lower, guaranteeing superior nutritional quality (Lozano et al., 2014).

\subsubsection{Spray-dryer}

The spray-drying process is an old technique, which arose due to the urgent need for food preservation. In the year of 1872, the researcher Percy, developed the first patent on the use of this technique, and from then on, the demand for the process increased (Barbosa, \& Teixeira, 2016; Percy, 1872). The spray-dryer's operating mechanism is based on the simultaneous exchange of heat and mass between the drying air and the liquid (which can be in solutions, suspensions or emulsions). In contact with a stream of hot air, the particles lose moisture and dry droplets of solid (final product) are formed (De Souza Lima, Ré, \& Arlabosse, 2020).

Although many factors influence the quality of spray-dried products, using this method, it is possible to guarantee the microbiological stability of powder products, since the absorption of moisture prevents the degradation process, moreover, with the weight and volume, storage and transportation costs will consequently be lower. Other advantages of this technique include, high reproducibility, applicability to materials sensitive to heat, simplicity and flexibility (Siacor et al., 2020; Arpagaus et al., 2018; Ziaee et al., 2019; Shishir, \& Chen, 2017).

A typical spray-dryer equipment consists of four main components: drying chamber, atomizer (nozzle), vacuum cleaner and collection cyclone, as can be seen in Figure 1. The general process occurs as follows, first the sample is atomized, generating droplets of defined sizes, then the atomized droplets pass through a high temperature gas flow that will result in the evaporation of all the solvent and the subsequent production of solid particles. Finally, the dry particles are properly separated from the outlet gas stream by cyclone (Huang et al., 2017).

Figura 1. Overview of spray-drying unit operation.

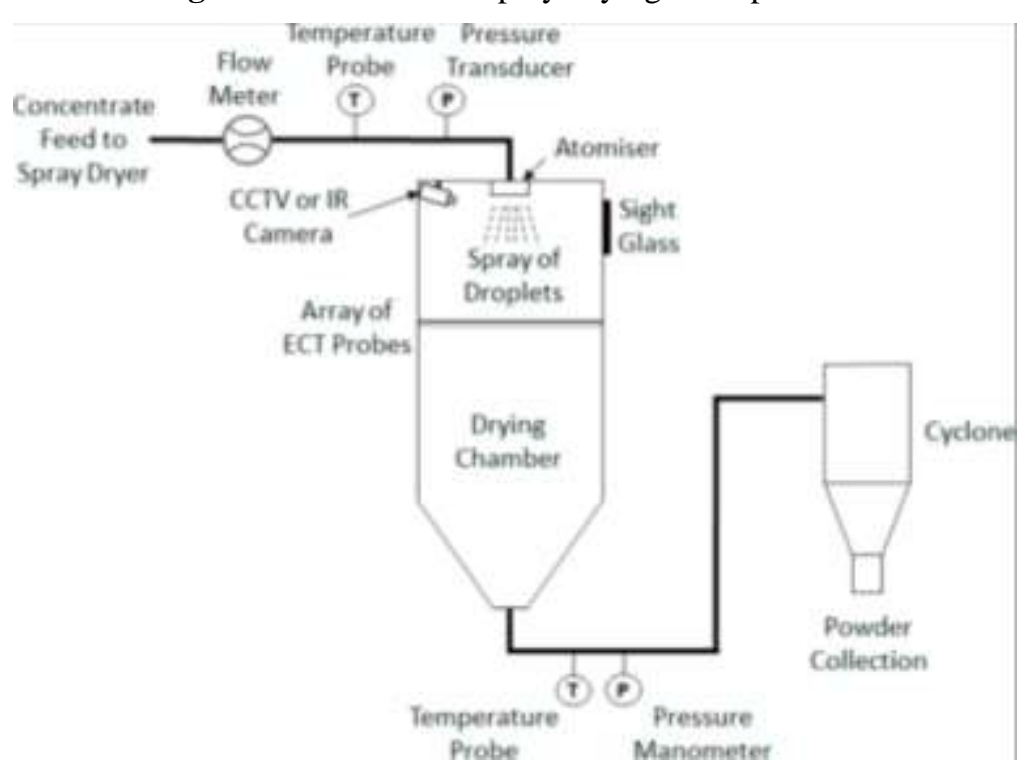

Fonte: Huang et al. (2017). https://ars.els-cdn.com/content/image/1-s2.0-S0260877418303649-egi10TWZBQ8KZD_lrg.jpg. 
The operation of the spray-dryer equipment can be changed by means of parameters such as the cycle mode, the different types of atomizers and the air flow pattern. There are two cycle modes in which the equipment can be operated, the closed circuit together with the use of a capacitor and the open loop. The first case is preferable for the preparation of aseptic formulations. In addition, in this mode, it is possible to reduce the release of organic solvents that can harm the environment and reduce the possible risks of explosion, since the process is carried out at high temperatures. The open mesh mode is preferable for aqueous or water-based raw materials. In general, there is no need to use the condenser, as the air coming from the environment is used as a drying gas stream (Rosa, Tsukada, \& Freitas, 2006).

Atomization is characterized as one of the most important steps in the drying process, as it mainly directly influences the properties of the final product such as particle size, morphology, among others. Several types of atomizers are available on the market, among them, rotary atomizer, single fluid nozzle, pneumatic nozzle and ultrasonic nozzle (Mujumdar, Huang, \& Chen, 2010; Baker, 1997).

Finally, the air flow pattern is based on the position of the atomizer in relation to the incoming air flow. Three types are available on the market, countercurrent co-current and mixed flow. The co-current configuration is used for drying sensitive materials at high temperatures, but can also be used for other types of materials. The countercurrent arrangement is commonly used for the production of detergents, fertilizers and some food substances. Finally, the mixed flow provides a wider application range, especially for materials with different degrees of thermal stability (Menon, Stojceska, \& Tassow, 2020).

This process is widely applied in treatments for preserving bovine milk and infant formulas, simultaneously, a possible option for human milk (Geankoplis, 1998). The spray-dryer treatment is used to eliminate water from the composition of bovine milk, capable of retaining a maximum of $5 \%$ water, where $95 \%$ corresponds to proteins, lactose and fat, mineral salts, etc (Guardiola Rodríguez, 2015).

In studies, the concepts of spray-dryer applications are comprehensive regarding dairy compounds (powdered milk, powdered casein, and powdered whey). Applicability on an industrial scale is presented, in addition to existing factors that influence the process, such as the composition of the food matrix (O'Sullivan, Norwood, O'Mahony, \& Kelly, 2019).

One of the advantages of applying the spray-dryer process is the minimization of storage, in addition to ease of transportation and longer product life. The protein composition can influence the reconstitution process (due to solubility), which can limit its use. One study evaluated the thermal stability during heating at $90{ }^{\circ} \mathrm{C}$ for $0,10,20$ and 30 minutes, it also evaluated sensory properties and volatile compounds; no differences in thermal stability were detected under these conditions. The tested products had a higher intensity of aroma and flavors compared to liquids. Therefore, it can be understood that the spray-dryer process can affect the taste and its functionality can be beneficial to certain foods according to the ingredient used (Carter, Patel, Barbano, \& Drake, 2018).

Spray-dryer drying is a high-value process, however it is the most common form of drying found in the dairy industry. The consequences associated with this process have been changes in flavor caused by lipid oxidation, products of the Maillard reaction and other forms (Smith, Campbell, \& Drake, 2016). Another disadvantage of drying would be the reduction of protein yield, through deposition on walls when applied at high temperature, which can lead to reduced recovery when reconstituted with water (Ozmen, \& Lancgrish, 2003).

In addition to spray-drying, there are other methods available, among them, non-conventional drying such as hybrid systems, heat pumps, superheated steam, vacuum, microwave, and others. Each of them will be briefly presented below (Anum, Ghafoor, \& Munir, 2016).

Hybrid drying systems can be defined by processes that use solar energy combined with various drying technologies, these include vacuum drying plus microwave drying; vacuum drying plus spray drying and fluidized milk plus heat pump 
(Menon, Stojceska, \& Tassow, 2020). These have higher energy efficiency, faster drying rates and higher quality of the products formed (Aktaş, Khanlari, Amini, \& Şevik, 2017).

Heat pump dryers are one of the effective methods nowadays. In its operation, moist air is generated as the condenser and compressor work simultaneously, and it is used to obtain the dry product, it is worth mentioning that the system is recirculatory, reaching energy efficiency of up to $100 \%$. Between lines, as the moist air passes through the evaporator, it is cooled in a matter of seconds to a temperature below its dew point, allowing the removal of moisture. Some of the advantages of this technique are the non-emission of polluting gases into the atmosphere, low energy consumption and high quality of the product generated (Gan, Ong, Chin, \& Law, 2017; Jia, Liu, Li, Fang, \& Chen, 2018).

The heated steam drying technique, on the other hand, is based on the application of steam at a temperature that exceeds the sample's boiling point (Jia, Liu, Li, Fang, \& Chen, 2018). The advantages of this technique are that it allows the drying of materials that are not sensitive to high temperatures, avoids oxidative reactions, maintains the color and nutrients of the sample. Among the foods in which heated steam drying is used, rice, meat, shrimp, pasta and grains are included (Kozanoglu, Mazariegos, Guerrero-Beltrán, \& Welti-Chanes, 2013; Speckhahn, Srzednicki, \& Desai, 2010; Prachayawarakorn, Soponronnarit, Wetchacama, \& Jaisut, 2002; Pronyk, Cenkowski, \& Muir, 2010; Ourassa et al., 2015).

Therefore, in vacuum drying, samples are subjected to a low pressure process. This condition favors the reduction of the boiling point of the water contained in the food, making the evaporation fast. The heat source used for this is a conduction process. The vacuum method is widely used for those foods sensitive to heat, and have a high amount of bioactive compounds (Parikh, 2015).

The microwave drying technique is based on exclusive volumetric heating, the process being facilitated by the use of electromagnetic radiation. It is widely used, as it generates high quality products, moreover, it is recommended for temperature sensitive samples, such as cultures, enzymes and proteins. Ambros, Foerst, and Kulozik (2018) evaluated microwave drying combined with vacuum for the preservation of probiotics and starter cultures, from their research, concluded that the microwave power directly interferes with the efficiency of the process, and the intermediate energy levels result in less drying time and higher survival rate.

Among the techniques analyzed, spray-drying is one of the oldest. The first industries to use were dairy followed by pharmaceuticals. Dairy compounds, especially human milk, are considered the most complete and adequate source for infants, as it has a balanced nutritional composition that includes all essential nutrients that assist in the child's healthy growth and development (Rydlewski et al., 2020). However, human milk is easily perishable due to the high humidity value found, and also the components of this matrix that can be affected by thermal processing, thus, the spray-dryer technique becomes fundamental for this matrix, forming products such as milk powder, powdered casein and powdered whey (Ziaee et al., 2019; O’Sullivan, Norwood, O’Mahony, \& Kelly, 2019).

Arreola et al. (2018) evaluated the effects of different treatments applied to human milk, and concluded that the spraydryer process with high pressure, ultravioleta-C (UV-C) radition and $\gamma$ irradiation preserved biological activities, in addition, Cavazos-Garduño et al. (2016) say they maintain good microbiological quality so alternative applications for conservation in human milk banks are considered. It is important to note that the drying techniques described in the course of this work can also be a good alternative for drying human milk, however, no specific studies have yet been found to prove this.

\subsubsection{High Hydrostatic Pressure (HPP)}

High hydrostatic pressure (HPP) processing is promising as an alternative for treatment in human milk, allowing the maintenance of unique nutritional components; Viazis; Farkas, and Jaykus (2008) data report the processing efficiency at 400 
MPa at 21 to $31^{\circ} \mathrm{C}$ compared to standard pasteurization of human milk banks. However, the authors indicate that an evaluation on inactivation of viral pathogens and spore-forming bacteria is needed.

The use of the high hydrostatic pressure process in human milk led to microbial decontamination for Staphylococcus aureus and Bacillus cereus, and preservation of the biotivity of the main components: activities of lipase ( $80 \%)$, $\alpha$ lactalbumin ( 96-99\%), casein ( 98-100\%), lysozyme ( 95-100\%), lactoferrin ( 93-97\%) and sIgA ( 63-64\%). Considerably, this process becomes effective in the face of weight gain and composition maintenance, in research applied to contamination by Bacillus cereus, it is concluded capable of avoiding post-treatment waste (Demazeau et al., 2018; Sousa, Delgadillo, \& Saraiva, 2016).

Currently, high pressure treatment is considered a new processing technique for food products, in which the product is treated in a container with adequate resistance to high pressure, usually in the range of 100-1000 MPa. Other processes, for example rapid pasteurization or spray-dryer, can affect milk properties by destabilizing proteins and minerals, consequently impairing the manufacture of derivatives, indicating a possible change in the application of high pressure treatment (Huppertz, Fox, de Kruif, \& Kelly, 2006; Júnior, Tribst, Ribeiro, \& Cristianini, 2019).

The effect of high hydrostatic pressure on pathogenic microorganisms is influenced by the type of microorganism and food matrix, among other variables under treatment conditions. This technology can be an alternative to pasteurization in human milk banks, as, in studies, conditions for bacterial inactivation were tested by applying pressure intensity of 593.96 MPa for 233 seconds. This model can be a useful tool to increase milk safety, considerably applicable in human milk banks (Rocha-Pimienta et al., 2020).

Also according to the literature, high pressure processing is considered an alternative to pasteurization, and it is responsible for eliminating pathogenic microorganisms from human milk, applying pressures from 400 to $800 \mathrm{MPa}$ evenly for a period of 5 to 10 minutes (Huppertz, Fox, de Kruif, \& Kelly, 2006). Because it is fast and does not involve high temperatures, this process provides food free of pathogens and without nutritional, sensory changes and in its original chemical composition (Considine, Kelly, Fitzgerald, Hill, \& Stleator, 2008).

Moltó-Puigmartí, Permanyer, Castellote, and López-Sabater (2011), evaluated the capacity of high pressure processing and compared it with Holder pasteurization, regarding the maintenance of fatty acid structures. In this study, three treatments were used with pressure variations of 400, 500 and $600 \mathrm{MPa}$, for 5 minutes. The initial water temperature, which acts as a pressure transfer medium, for all treatments was $12{ }^{\circ} \mathrm{C}$ and the final water temperature was $22{ }^{\circ} \mathrm{C}$ for $400 \mathrm{MPa}$ pressure, $24.5^{\circ} \mathrm{C}$ for $500 \mathrm{MPa}$ and $27^{\circ} \mathrm{C}$ to $600 \mathrm{MPa}$. As a final result of the three treatments, the processing did not change the fatty acid composition of human milk in all conditions evaluated, when compared with the fatty acid concentrations of pasteurized human milk by Holder pasteurization.

Contador, Delgado, García-Parra, Garrido, and Ramírez (2015), analyzed the volatile profile of human milk with distinct high pressure processing ranging from 400 and $600 \mathrm{MPa}$ for 3 and 6 minutes, comparing with Holder pasteurization and with a control sample (without processing). 46 different volatile compounds were identified in human milk samples, the most abundant being aliphatic hydrocarbons. The results of this study demonstrated that the volatile compounds of human milk samples subjected to pressures of 400 and $600 \mathrm{MPa}$ for 3 minutes remained stable when compared to samples of control human milk, unlike the application of $600 \mathrm{MPa}$ for 6 minutes, which altered the original compounds. Thus, the application of pressures of 400 or $600 \mathrm{MPa}$ for 3 minutes can be an alternative to conventional pasteurization applied in human milk banks.

Viazis, Farkas and Allen (2007) also studied high pressure processing (400 MPa) comparing with slow pasteurization (62.5 ${ }^{\circ} \mathrm{C}$ for 30 minutes), in relation to immunoglobulin A and the activity of lysozyme in human milk. The results obtained showed that the samples submitted to high pressure preserved the analyzed compounds, to the detriment of slow pasteurization, 
suggesting that the studied process can be used as a potential alternative to slow pasteurization of human milk in human milk banks.

Permanyer et al. (2010) investigated the influence of high pressure treatments (400, 500 and $600 \mathrm{MPa}$ for 5 minutes) on the $\operatorname{IgA}$ content and on the bacterial load compared to standard pasteurization $\left(62.5^{\circ} \mathrm{C}\right.$ for 30 minutes $)$. As a result, they found that all three high pressure treatments were as effective as pasteurization in reducing the bacterial load of the human milk samples studied. Regarding IgA, in processing at $400 \mathrm{MPa}, 100 \%$ of the $\operatorname{IgA}$ content was preserved in the whey, while only $72 \%$ was preserved in the pasteurized whey at $62.5^{\circ} \mathrm{C}$ for 30 minutes, in relation to the 500 and 600 treatments $\mathrm{MPa}, \operatorname{IgA}$ retention was 87.9 and $69.3 \%$, respectively. Indicating that processing at $400 \mathrm{MPa}$ for 5 minutes when evaluating these components is the most effective treatment.

Mayayo et al. (2014) studied the denaturation of lactoferrin in pasteurization treatments $\left(65{ }^{\circ} \mathrm{C}\right.$ for 30 minutes) and high pressure, at pressures of 300, 400, 500 and $600 \mathrm{MPa}$ for 15 minutes. The results found for pressures of 300, 400, 500 and $600 \mathrm{MPa}$ for denaturation were $9 \%, 23 \%, 34 \%$ and $48 \%$, respectively, while pasteurization denatured $80 \%$. Suggesting that high pressure processing is a viable alternative to pasteurization.

Contador, Delgado-Adámez, Delgado, Cava, and Ramírez (2013) studied the effect of high pressure (400 and 600 $\mathrm{MPa}$, for 3 and 6 minutes) comparing with Holder pasteurization, evaluating the leukocyte and immunoglobulin content (IgM, $\operatorname{IgA}$ and $\operatorname{IgG}$ ). Pressure treatment at $400 \mathrm{MPa}$ (for 3 or 6 minutes) maintained immunoglobulin levels (IgM, $\operatorname{IgA}$ and $\operatorname{IgG}$ ) in human milk better than standard pasteurization. The $600 \mathrm{MPa}$ treatment reduced the levels of immunoglobulins. Regarding leukocytes, high pressure and standard pasteurization destroyed most of them. Showing that only for immunoglobulin, high pressure can be an adequate alternative, since it has maintained the original levels better.

Delgado, Cava, Delgado, and Ramírez (2014) studied the influence of high pressure thermal processing (300, 600 or $900 \mathrm{MPa}$ at an initial temperature of 50,65 or $80^{\circ} \mathrm{C}$, for 1 minute) on the levels of tocopherols, fatty acids, cytokines, leukocytes and immunoglobulins ( $\operatorname{IgM}, \operatorname{IgA}$ and $\operatorname{IgG}$ ) in human milk. As a result, they found that milk treated at 65 or $80^{\circ} \mathrm{C}$ at any pressure intensity caused a significant decrease in the content of alpha-tocopherol compared to untreated (raw) milk. Some fatty acids have also been reduced with high pressure treatment. However, in relation to cytokines it had a minimal effect. Leukocytes did not survive any of the treatments applied.

Pitino et al. (2019) compared the standard pasteurized treatment, with UV-C irradiation ( $250 \mathrm{~nm}, 25$ minutes) and high hydrostatic pressure (500 MPa, 8 minutes) in human milk, evaluating macronutrients, heat-sensitive micronutrients (vitamin C, folate) and bioactive components (bile salt stimulated lipase (BSSL), lysozyme, lactoferrin). As a result, they obtained that folate, lactoferrin and BSSL were reduced in all techniques, except at high pressure, and even though all treatments reduced vitamin C. Since lysozyme activity was reduced in UV-C irradiation, unaffected by standard pasteurization and high pressure. In conclusion, the authors found that high pressure preserves the components evaluated in human milk better than standard pasteurization, which is applied in human milk banks.

Franch et al. (2010) evaluated the content of IgA, EGF, TGF- $\beta 1$, TGF- $\beta 2$, IL-6, IL-8, IL-10, IL-13, TNF- $\alpha$ and TNF$\mathrm{RI}$ in human milk by comparing human milk without processing, pasteurized $\left(62.5^{\circ} \mathrm{C}\right.$ for 30 minutes) and with high hydrostatic pressure (400, 500 and $600 \mathrm{MPa}$ for 5 minutes at $10-12{ }^{\circ} \mathrm{C}$ ). As a result, they obtained that the IgA content was reduced with the standard pasteurization and that the high pressure treatment at $400 \mathrm{MPa}$ maintained the best concentrations. Thus confirming that high pressure processing in human milk can be applied as an alternative to standard pasteurization in human milk banks. 


\subsubsection{High Temperature and Short Time (HTST)}

Another method of pasteurization, known as high temperature and short time (HTST), employs heating at $72{ }^{\circ} \mathrm{C}$ for 15 seconds. Presented for the first time by Holsinger, Rajkowski, and Stabel (1997), the results demonstrated that HTST preserves the sensory characteristics and nutritional values of human milk, still guaranteeing less degradation of proteins and vitamins, when compared to other pasteurization methods.

The literature presents several studies comparing HTST with Holder pasteurization and other processes for human milk, some of which are described below. Salcedo et al. (2018), evaluated the application of industrial treatments to donated human milk and its influence on gangliosides, also called glycosphingolipids, identified as bioactive compounds with antibacterial and anti-inflammatory properties. The treatments used were $63{ }^{\circ} \mathrm{C}$ for 30 minutes, $72{ }^{\circ} \mathrm{C}$ for 15 seconds, $127{ }^{\circ} \mathrm{C}$ for 5 seconds and $140{ }^{\circ} \mathrm{C}$ for 6 seconds, for a period of 3 months, after storage at 4 and $23{ }^{\circ} \mathrm{C}$. The result of all the treatments used guaranteed the stability of the analyzed compounds.

Romeu-Nadal, Castellote, Gayà, and López-Sabater (2008) also studied the effect of slow $\left(62.5^{\circ} \mathrm{C}\right.$ for 30 minutes) and fast $\left(100^{\circ} \mathrm{C}\right.$ for 5 minutes) pasteurizations on the fatty acid composition of human milk, reporting that fatty acids were not affected by the methods. However, the other components studied (ascorbic acid, dehydroascorbic acid and tocopherols) showed a reduction in its concentrations, compared to rapid pasteurization. Fidler, Sauerwald, Demmelmair, and Koletzko (2001) studied fatty acids in two groups of human milk in relation to raw milk, one pasteurized $\left(62.5^{\circ} \mathrm{C}\right.$ for 30 minutes) and another sterilized $\left(120^{\circ} \mathrm{C}\right.$ for 30 minutes). The saturated and monounsaturated fatty acids did not suffer significant differences in its concentrations ( $\mathrm{p}<0.05$ ), however there was a decrease in the relative percentage of polyunsaturated fatty acids, in which the eicosapentaenoic (EPA, 20:5n-3) reduced 0.2\%, the acid docosapentaenoic (DPA, 22:5n-3) 0.7\%, docosa-hexaenoic (DHA, 22:6n-3) 0.2\%, dihomo-linolenic acid (20:3n-6) $0.2 \%$ and arachidonic acid (AA, 22:4n-6) $1.6 \%$ in pasteurized human milk, compared to raw human milk. In relation to sterilized human milk, EPA reduced 1.5\%, DPA $3.8 \%$, DHA 2.7\%, di-homolinolenic acid 2.1\%, DHA $1.6 \%$ and AA 5.3\%, thus showing that sterilization led to a greater reduction in the values of fatty acids.

Nebbia et al. (2020) studied HTST $\left(72{ }^{\circ} \mathrm{C}\right.$ for 15 seconds) as an alternative to Holder pasteurization $\left(62.5^{\circ} \mathrm{C}\right.$ for 30 minutes) to increase the preservation of bioactive compounds in human milk, noting that there was an increase in proteins on the surface of blood cells fat after pasteurization, to a lesser extent in HTST than in Holder pasteurization.

Parrón et al. (2018) evaluated in their study different pasteurization treatments, such as standard (62.5 C for 30 minutes), HTST ( $75^{\circ} \mathrm{C}$ for 20 seconds) and high pressure (600 MPa for 15 minutes) in human milk, on its components such as immunoglobulin A (IgA), lactoferrin, mucins and lactaderine. In conclusion, HTST and high pressure pasteurization treatments were less harmful to these components, that is, reducing smaller quantities, than standard pasteurization.

A new device was developed to pasteurize near $10 \mathrm{~L}$ of human milk per hour. This system, called small-scale continuous high-temperature short-term pasteurizer (HTST), was compared with Holder pasteurization. In general, both processes evaluated the biochemical quality of secretory immunoglobins, protein profile, lysozyme, activities of lipases stimulated by bile salts (BSSL) contained in milk. The results obtained showed that HTST pasteurization proved to be more effective, as it was able to efficiently pasteurize human milk, significantly retaining the IgAs content and bile activity, as well as the non-appearance of harmful microorganisms, thus ensuring the safety of consumption of this sample (Giribaldi et al., 2016).

Aceti et al. (2020) compared the effectiveness of Holder pasteurization, with HTST and high pressure (600 MPa for 3 minutes) in the preservation of some human milk bioactive components, such as the total protein content, immunoglobulin A (IgA) and lactoferrin. As a result, they obtained that both HTST pasteurization and high pressure preserved proteins better, compared to standard pasteurization. 
Donalisio et al. (2018) evaluated the effect of Holder pasteurization and HTST pasteurization on the antiviral properties of human milk, as in cytomegalovirus, respiratory syncytial virus, rotavirus and herpes virus type 2 , concluding that HTST pasteurization better preserved the antiviral activity of human milk than Holder pasteurization.

Escuder-Vieco, Espinosa-Martos, Rodríguez, fernández, and Pallás-Alonso (2018a) compared the effects of Holder and HTST pasteurization treatments, with temperatures and times of 70,72 and $75{ }^{\circ} \mathrm{C}$ for 5 to 25 seconds, in concentrations of immunoglobulins A, G and M, and human milk leptin. The concentration of $\operatorname{IgA}, \operatorname{IgG}, \operatorname{IgM}$ and leptin in human milk was higher after HTST pasteurization than after Holder pasteurization, which is currently applied in human milk banks.

Klotz et al. (2017) explored in their study the antibacterial efficacy of an alternative HTST pasteurization treatment of human milk and its effect on marker proteins, compared to Holder pasteurization. As a conclusion, they obtained that the HTST pasteurization treatment retained some bioactive properties of human milk, showing to have antibacterial efficacy similar to Holder pasteurization.

Escuder-Vieco et al. (2018b) compared the standard pasteurization of milk banks, with the HTST pasteurization (72 ${ }^{\circ} \mathrm{C}$ for 10 seconds) in human milk, showing that the HTST processing allowed to reach the microbiological safety objectives established by the milk banks and, having an impact lower in the composition of furosine when compared to standard pasteurization.

Terpstra et al. (2007) carried out an experiment to verify the effects of HTST at $72{ }^{\circ} \mathrm{C}$ for 16 seconds comparing with Holder pasteurization on the biological load of human milk, concluding that HTST is as effective as standard pasteurization for the elimination of pathogenic microorganisms, which are harmful to infants in human milk.

\subsubsection{Short-wave ultraviolet irradiation (UV-C)}

Ultraviolet (UV) irradiation is classified as a non-thermal disinfection method (Tran, \& Farid, 2004). UV treatment has broad electromagnetic spectra between $100 \mathrm{~nm}$ and $400 \mathrm{~nm}$, which are mainly classified into UV-A (320-400 nm), UV-B (280-320 nm), UV-C (200-280 nm); are effective in terms of microbial inactivation (Coohill, \& Sagripanti, 2008) and are responsible for its high germicidal action against sporulated and non-sporulated bacteria, viruses, vegetative cells and fungi (Gayan, Alvarez, \& Condón, 2013; Tran, \& Farid, 2004).

Short-wave ultraviolet radiation (UV-C) is commonly used for sterilizing drinking water. However, its low transmittance within opaque liquids limits its use. The results showed that UV radiation in combination with heat $\left(110{ }^{\circ} \mathrm{C}, 30\right.$ seconds) can be an alternative to the sterilization of skimmed bovine's milk at lower temperatures compared to the treatment with ultra-high temperature (UHT) $\left(135^{\circ} \mathrm{C}, 3\right.$ seconds) (Ansari, Ismail, \& Farid, 2019).

There are difficulties in UV-C treatment in human milk, due to its high absorption coefficient, which increases with the total concentration of solids, limiting the depth of photon penetration, this limitation can be overcome by applying a vertical flow around from a UV-C source (Christen, Lai, Harmann, Harmann, \& Geddes, 2013a). UV-C irradiation of human milk preserves significantly higher levels of immune proteins than Holder pasteurization, resulting in bacteriostatic properties similar to those of raw human milk (Christen, Lai, Hartmann, Hartmann, \& Geddes, 2013b).

The study by Christen, Lai, Hartmann, Hartmann, \& Geddes (2013b) demonstrates that irradiation with UV-C results in better preservation of individual immunoglobulin immune proteins. Immunoglobulin A (known mainly as IgA), lysozyme and lactoferrin with significantly higher retention rates compared to Holder pasteurization. However, due to the complex nature of human milk, it is difficult to accurately determine the individual contribution of these major immune proteins to bacteriostatic properties, and some effects can be synergistic.

In particular, interest in sterilization by UV radiation is growing, credits to its cost-benefit and efficiency in a wide range of microorganisms and its ease of installation and use. The intensity of light, in all fluid points, depends both on the 
power of the lamps and on the effect of the UV light penetration into the fluid medium. The penetration effect of UV-C radiation depends on the type of liquid, its absorption coefficient, the soluble solutes present in the liquid and the matter in suspension. Basically due to a volume of $6 \%$ dry matter and UV light penetrates the liquid only a few millimeters, instead of penetrating several centimeters, as in the case of water. For this reason, it is applied in clear fluids (Buhler et al., 2019).

Irradiation with UV-C is able to reduce vegetative bacteria in human milk to the requirements of the milk bank guidelines, without loss of lipase activity stipulated by bile salt and alkaline phosphatase activity and without alteration of fatty acids (Christen, Lai, Hartmann, Hartmann, \& Geddes, 2013a).

Irradiation with UV-C induces chemical reactions that damage deoxyribonucleic acid (DNA), which in turn leads to photoproducts, such as pyrimidine dimers, and cross-linking with proteins. On rare occasions, damage to the DNA strands occurs (Shama, 1999). In another study, the retention of immune proteins, including lactoferrin, lysozyme and IgAs, was found to depend on exposure doses during irradiation with UV-C. A lower dosage resulted in a higher retention rate and vice-versa. However, UV-C irradiation preserved significantly higher levels of immune proteins than high-pressure processing, thus contributing to slower bacterial growth and greater bactericidal capacity for UV-C-treated human milk than Holder pasteurization (Christen, Lai, Hartmann, Hartmann, \& Geddes, 2013b).

In the study by Christen, Lai, Hartmann, Hartmann, \& Geddes (2013a) from 24 fatty acids tested, 19 remained intact. The concentration of fatty acids varied widely between individual samples of untreated human milk, but did not change significantly during treatment with UV-C. The dosages of UV-C applied in this study did not significantly alter the fatty acid profile of human milk, in terms of the total amount, the individual quantities and distribution of fatty acids. This finding is corroborated by the study by Matak et al. (2007) on goat's milk, where the fatty acid profile was not significantly altered by irradiation with UV-C.

UV-C has a high germicidal effect, between 250 and $270 \mathrm{~nm}$, and it is capable of destroying bacteria, viruses, protozoa, yeasts, fungi and algae, although it has a low penetration capacity that limits its use to liquid foods and flat surfaces (Jay, 2000). In studies on microbiological safety in the face of new technologies, particularly for UV-C irradiation, there is a discrepancy about the reported tests and processing conditions, which do not allow conclusions to be drawn about whether and to what extent alternative technologies are capable of improve the nutritional quality and bioactivity of pasteurized human milk (Peila et al., 2016).

\section{General Overview of the Process}

In general, most of the processes mentioned above are effective in maintaining the quality of human milk, however it is noted that there are advantages and disadvantages in the application of each of them, in order to clarify this situation, Table 1 was elaborated.

Table 1 - Advantages and disadvantages of each processing of possible application to human milk.

\begin{tabular}{|c|c|c|}
\hline Process & Advantages & Disadvantages \\
\hline Holder Pasteurization & $\begin{array}{l}\text { Reduction of microbial load; } \\
\text { Pathogenic inactivation; } \\
\text { No change in fatty acids and soluble vitamins; } \\
\text { Ease of operation. }\end{array}$ & $\begin{array}{l}\text { Possible loss of nutritional and/or biological } \\
\text { quality; } \\
\text { Possible loss of soluble vitamins; }\end{array}$ \\
\hline
\end{tabular}




\begin{tabular}{|c|c|c|}
\hline & $\begin{array}{l}\text { Reduction of product volume, reducing the space for storage and } \\
\text { transportation. }\end{array}$ & \\
\hline Spray- dryer & $\begin{array}{l}\text { Ensures microbiological stability; } \\
\text { High reproducibility; } \\
\text { Applicability to heat sensitive materials; } \\
\text { Simplicity and flexibility; } \\
\text { Reduction of product volume, reducing the space for storage and } \\
\text { transportation. }\end{array}$ & $\begin{array}{l}\text { Reduction of protein yield, so the protein } \\
\text { composition can influence the reconstitution } \\
\text { process (due to solubility); } \\
\text { Flavor changes caused by lipid oxidation, } \\
\text { products of the Maillard reaction and other } \\
\text { forms. }\end{array}$ \\
\hline $\begin{array}{l}\text { Short-wave Ultraviolet } \\
\text { Irradiation (UV-C) }\end{array}$ & $\begin{array}{l}\text { Presents germicidal action against sporulated and non-sporulated } \\
\text { bacteria, viruses, vegetative cells, and fungi; } \\
\text { Preserves individual immune proteins from immunoglobulins and } \\
\text { fatty acid content; } \\
\text { Ease of installation and use of the equipment. }\end{array}$ & $\begin{array}{l}\text { The process may not be effective because the } \\
\text { total concentration of solids that is a limiting } \\
\text { factor in the depth of photon penetration. }\end{array}$ \\
\hline
\end{tabular}

Source: Authorship (2021).

\section{Final Considerations}

In view of the research carried out, followed by scientific bases, it can be concluded that human milk is rich in nutrients, being extremely important to use a processing that maintains its nutritional and immunological properties for a prolonged period. However, there is still a long way of research to be performed in relation to the technologies used in the processing of human milk, and its propagated quality, and the UV-C technology must be the one that deserves the most attention and studies, because even if showing promise, there are few studies reported in the literature that employ this technique for the processing and conservation of human milk. New studies are needed to evaluate the behavior of human milk in different application parameters during the processing studied in this review.

\section{Acknowledgments}

The authors would like to thank the Conselho Nacional de Desenvolvimento Científico e Tecnológico (CNPq), Coordenação de Aperfeiçoamento de Pessoal de Nível Superior (CAPES) and Fundação Araucaria for the financial assistance, to the research group APLE-A/CNPq.

\section{References}

Aceti, A., Cavallarin, L., Martini, S., Giribaldi, M., Vitali, F., Ambretti, S., \& Corvaglia, L. (2020). Effect of Alternative Pasteurization Techniques on Human Milk's Bioactive Proteins. Journal of Pediatric Gastroenterology and Nutrition, 70(4), 508-512.

Akinbi, H., Meinzen-Derr, J., Auer, C., Ma, Y., Pullum, D., Kusano, R., \& Zimmerly, K. (2010). Alterations in the host defense properties of human milk following prolonged storage or pasteurization. Journal of pediatric gastroenterology and nutrition, 51(3), $347-352$.

Aktaş, M., Khanlari, A., Amini, A., \& Şevik, S. (2017). Performance analysis of heat pump and infrared-heat pump drying of grated carrot using energyexergy methodology. Energy Conversion and Management, 132, 327-338.

Ambros, S., Foerst, P., \& Kulozik, U. (2018). Temperature-controlled microwave-vacuum drying of lactic acid bacteria: Impact of drying conditions on 
process and product characteristics. Journal of Food Engineering, 224, 80-87.

Ansari, J. A., Ismail, M., \& Farid, M. (2019). Investigate the efficacy of UV pretreatment on thermal inactivation of Bacillus subtilis spores in different types of milk. Innovative Food Science \& Emerging Technologies, 52, 387-393.

Anum, R., Ghafoor, A., \& Munir, A. (2017). Study of the drying behavior and performance evaluation of gas fired hybrid solar dryer. Journal of Food Process Engineering, 40(2), e12351.

Arreola, A. R., Lacroix, M., Pacheco, J. R. S., Morales, E. G., Padilla, J. A. G., Castellanos, E. A., \& Uscanga, B. R. A. (2018). Assessment of the Biological Activity in Human Milk Power Treated with Different Processes for Their Conservation. Journal of Food and Nutrition Research, 6(5), 329-334.

Assegehegn, G., Brito-de la Fuente, E., Franco, J. M., \& Gallegos, C. (2019). The importance of understanding the freezing step and its impact on freezedrying process performance. Journal of pharmaceutical sciences, 108(4), 1378-1395.

Baker, C.G.J. (1997) Industrial Food Drying. Springer Science \& Business Media.

Ballard, O., \& Morrow, A. L. (2013). Human milk composition: nutrients and bioactive factors. Pediatric Clinics, 60(1), 49-74.

Barbosa, J., \& Teixeira, P. (2017). Development of probiotic fruit juice powders by spray-drying: A review. Food Reviews International, 33(4), 335-358.

Basholli-Salihu, M., Mueller, M., Salar-Behzadi, S., Unger, F. M., \& Viernstein, H. (2014). Effect of lyoprotectants on $\beta$-glucosidase activity and viability of Bifidobacterium infantis after freeze-drying and storage in milk and low pH juices. LWT-Food Science and Technology, 57(1), 276-282.

Borges, M. S., Oliveira, A. M. D. M., Hattori, W. T., \& Abdallah, V. O. (2018). Quality of human milk expressed in a human milk bank and at home. Jornal de Pediatria (Versão em Português), 94(4), 399-403.

Brasil (2004). Agência Nacional de Vigilância Sanitária. Regulamento Técnico para o gerenciamento de resíduos de serviços de saúde, Resolução no 306 de 7 de Dezembro de 2004. Anvisa: Brasília, 2004.

Brasil (2006). Agência Nacional de Vigilância Sanitária. Manual de gerenciamento de resíduos de serviços de saúde. Anvisa: Brasília, 2006 (Série Tecnologia em Serviços de Saúde).

Brasil (2008). Ministério da Saúde. Agência Nacional de Vigilância Sanitária. Banco de Leite Humano: funcionamento, prevenção e controle de riscos. Anvisa: Brasília, 2008.

Briere, C. E., McGrath, J. M., Jensen, T., Matson, A., Finck, C., Ikuta, L., \& Zukowsky, K. (2016). Breast milk stem cells. Advances in Neonatal Care, 16(6), 410-419.

Buhler, S., Solari, F., Gasparini, A., Montanari, R., Sforza, S., \& Tedeschi, T. (2019). UV irradiation as a comparable method to thermal treatment for producing high quality stabilized milk whey. Lwt, 105, 127-134.

Carter, B., Patel, H., Barbano, D. M., \& Drake, M. (2018). The effect of spray drying on the difference in flavor and functional properties of liquid and dried whey proteins, milk proteins, and micellar casein concentrates. Journal of dairy science, 101(5), 3900-3909.

Castro, A. J., Navarro, H. R., Solís, P. J., Salazar, Q. I., Macías, L. G., Barrera, D. L. J., \& Aguilar, U. B. (2017). Impact of pasteurization/freeze-drying on available immunoglobulin content of the mature human milk. Use in human milk banking of hospitals. Nutricion hospitalaria, $34(4), 899$.

Cavazos-Garduño, A., Serrano-Niño, J. C., Solís-Pacheco, J. R., Gutierrez-Padilla, J. A., González-Reynoso, O., García, H. S., \& Aguilar-Uscanga, B. R. (2016). Effect of pasteurization, freeze-drying and spray drying on the fat globule and lipid profile of human milk. J Food Nutr Res, 4(5), 296-302.

Challener, C. A. (2017). For lyophilization, excipients really do matter.

Christen, L., Lai, C. T., Hartmann, B., Hartmann, P. E., \& Geddes, D. T. (2013). Ultraviolet-C irradiation: a novel pasteurization method for donor human milk. PLoS One, 8(6), e68120.(a)

Christen, L., Lai, C. T., Hartmann, B., Hartmann, P. E., \& Geddes, D. T. (2013). The effect of UV-C pasteurization on bacteriostatic properties and immunological proteins of donor human milk. PLOS one, 8(12), e85867.(b)

Considine, K. M., Kelly, A. L., Fitzgerald, G. F., Hill, C., \& Sleator, R. D. (2008). High-pressure processing-effects on microbial food safety and food quality. FEMS microbiology letters, 281(1), 1-9.

Contador, R., Delgado, F. J., García-Parra, J., Garrido, M., \& Ramírez, R. (2015). Volatile profile of breast milk subjected to high-pressure processing or thermal treatment. Food chemistry, 180, 17-24.

Contador, R., Delgado-Adámez, J., Delgado, F. J., Cava, R., \& Ramírez, R. (2013). Effect of thermal pasteurisation or high pressure processing on immunoglobulin and leukocyte contents of human milk. International Dairy Journal, 32(1), 1-5.

Coohill, T. P., \& Sagripanti, J. L. (2008). Overview of the inactivation by $254 \mathrm{~nm}$ ultraviolet radiation of bacteria with particular relevance to biodefense. Photochemistry and photobiology, 84(5), 1084-1090.

de Andrade, K. D., do Nascimento Rangel, A. H., de Araújo, V. M., de Medeiros, H. R., Bezerra, K. C., Bezerril, R. F., \& de Lima Júnior, D. M. (2014). Qualidade do leite bovino nas diferentes estações do ano no estado do Rio Grande do Norte. Revista Brasileira de Ciência Veterinária, 21(3).

de Oliveira, S. C., Deglaire, A., Ménard, O., Bellanger, A., Rousseau, F., Henry, G., \& Bourlieu, C. (2016). Holder pasteurization impacts the proteolysis, lipolysis and disintegration of human milk under in vitro dynamic term newborn digestion. Food Research International, 88, $263-275$. 
de Souza Lima, R., Ré, M. I., \& Arlabosse, P. (2020). Drying droplet as a template for solid formation: A review. Powder Technology, 359, $161-171$.

Delgado, F. J., Cava, R., Delgado, J., \& Ramírez, R. (2014). Tocopherols, fatty acids and cytokines content of holder pasteurised and high-pressure processed human milk. Dairy Science \& Technology, 94(2), 145-156.

Demazeau, G., Plumecocq, A., Lehours, P., Martin, P., Couëdelo, L., \& Billeaud, C. (2018). A new high hydrostatic pressure process to assure the microbial safety of human milk while preserving the biological activity of its main components. Frontiers in public health, $6,306$.

do Vale Morais, A. R., do Nascimento Alencar, É., Júnior, F. H. X., De Oliveira, C. M., Marcelino, H. R., Barratt, G., \& Elaissari, A. (2016). Freeze-drying of emulsified systems: A review. International journal of pharmaceutics, 503(1-2), 102-114.

Donalisio, M., Rittà, M., Francese, R., Civra, A., Tonetto, P., Coscia, A., \& Lembo, D. (2018). High Temperature-Short Time Pasteurization Has a Lower Impact on the Antiviral Properties of Human Milk Than Holder Pasteurization. Frontiers in pediatrics, 6, 304.

Dórea, J. G., Fenton, S. E., LaKind, J. S., \& Berlin Jr, C. M. (2012). Researching chemicals in human milk can be conducted without discouraging breastfeeding. Bosnian journal of basic medical sciences, 12(2), 137-138.

Escuder-Vieco, D., Espinosa-Martos, I., Rodríguez, J. M., Corzo, N., Montilla, A., Siegfried, P., \& Fernández, L. (2018). High-temperature short-time pasteurization system for donor milk in a human milk bank setting. Frontiers in microbiology, 9, 926.

Escuder-Vieco, D., Espinosa-Martos, I., Rodríguez, J. M., Fernández, L., \& Pallás-Alonso, C. R. (2018). Effect of HTST and holder pasteurization on the concentration of immunoglobulins, growth factors, and hormones in donor human milk. Frontiers in immunology, 9, 2222.

Ewaschuk, J. B., \& Unger, S. (2015). Human milk pasteurization: benefits and risks. Current opinion in clinical nutrition and metabolic care, $18(3), 269-275$.

Fidler, N., Sauerwald, T. U., Demmelmair, H., \& Koletzko, B. (2001). Fat content and fatty acid composition of fresh, pasteurized, or sterilized human milk. In Bioactive Components of Human Milk (pp. 485-495). Springer, Boston, MA.

Franch, A., Audí, C., Ramírez-Santana, C., Permanyer, M., Pérez-Cano, F. J., Moltó-Puigmartí, C., \& Castellote, C. (2010). Banked human milk treatment and immunoactive factors content. Comparison with high pressure processing. Proceedings of the Nutrition Society, 69(OCE3).

Franklin, P., \& Volk, A. A. (2019). Breast Feeding.

Fugate, K., Hernandez, I., Ashmeade, T., Miladinovic, B., \& Spatz, D. L. (2015). Improving human milk and breastfeeding practices in the NICU. Journal of Obstetric, Gynecologic \& Neonatal Nursing, 44(3), 426-438.

Gan, S. H., Ong, S. P., Chin, N. L., \& Law, C. L. (2017). A comparative quality study and energy saving on intermittent heat pump drying of Malaysian edible bird's nest. Drying Technology, 35(1), 4-14.

Gao, C., Miller, J., Middleton, P. F., Huang, Y. C., McPhee, A. J., \& Gibson, R. A. (2019). Changes to breast milk fatty acid composition during storage, handling and processing: A systematic review. Prostaglandins, Leukotrienes and Essential Fatty Acids, 146, 1-10.

Geankoplis, C. J. (1982). Procesos de transporte y operaciones unitarias (No. 620 G4Y).

Giribaldi, M., Coscia, A., Peila, C., Antoniazzi, S., Lamberti, C., Ortoffi, M., \& Cavallarin, L. (2016). Pasteurization of human milk by a benchtop hightemperature short-time device. Innovative Food Science \& Emerging Technologies, 36, 228-233.

Grazziotin, A. L., Grazziotin, M. C., \& Letti, L. A. (2010). Descarte de leite humano doado a Banco de Leite antes e após medidas para reduzir a quantidade de leite imprópria para consumo. Jornal de Pediatria, 86(4), 290-294.

Guardiola Rodríguez, E. (2015). Elaboración de bases lácteas en polvo mediante secado por atomización para fabricación de chocolate.

Guimarães, V.; Almeida, J. A. G.; \& Novak, F. R. (2006) Distribuição: cuidados para manipulação do leite humano ordenhado em ambiente hospitalar. In: Normas Técnicas para o Banco de Leite Humano.

Guo, M. (Ed.). (2019). Whey Protein Production, Chemistry, Functionality, and Applications. John Wiley \& Sons.

Herrington, B. L. Pasteurização. Milk And Mil Processing, McGraw-Hill, (1948), 166-178.

Holsinger, V. H., Rajkowski, K. T., \& Stabel, J. R. (1997). Milk pasteurisation and safety: a brief history and update. Revue scientifique et technique-Office international des epizooties, 16(2), 441-466.

Huang, S., Vignolles, M. L., Chen, X. D., Le Loir, Y., Jan, G., Schuck, P., \& Jeantet, R. (2017). Spray drying of probiotics and other food-grade bacteria: A review. Trends in food science \& technology, 63, 1-17.

Huppertz, T., Fox, P. F., de Kruif, K. G., \& Kelly, A. L. (2006). High pressure-induced changes in bovine milk proteins: a review. Biochimica et Biophysica Acta (BBA)-Proteins and Proteomics, 1764(3), 593-598.

Jia, Z., Liu, B., Li, C., Fang, T., \& Chen, J. (2018). Newly designed superheated steam dryer bearing heat recovery unit: Analysis of energy efficiency and kinetics of Kelp drying. Drying Technology, 36(13), 1619-1630.

Johnston, M., Landers, S, Noble, L, Szucs, K., \& Viehmann, L. (2012). Breastfeeding and the use of human milk. Pediatrics, 129(3), e827-e841.

Júnior, B. R. D. C. L., Tribst, A. A. L., Ribeiro, L. R., \& Cristianini, M. (2019). High pressure processing impacts on the hydrolytic profile of milk coagulants. Food bioscience, 31, 100449. 
Katke, R., Walinjkar, S., Saraogi, M., \& Tawre, P. (2015). Practicalities and benefits of human milk banks in India. International Journal of Gynecology \& Obstetrics, 129(1), 83-84.

Klotz, D., Joellenbeck, M., Winkler, K., Kunze, M., Huzly, D., \& Hentschel, R. (2017). High-temperature short-time pasteurisation of human breastmilk is efficient in retaining protein and reducing the bacterial count. Acta Paediatrica, 106(5), 763-767.

Kozanoglu, B., Mazariegos, D., Guerrero-Beltrán, J. A., \& Welti-Chanes, J. (2013). Drying kinetics of paddy in a reduced pressure superheated steam fluidized bed. Drying Technology, 31(4), 452-461.

Kumar, R. K., Singhal, A., Vaidya, U., Banerjee, S., Anwar, F., \& Rao, S. (2017). Optimizing nutrition in preterm low birth weight infants-Consensus summary. Frontiers in nutrition, 4, 20.

Lozano, B., Castellote, A. I., Montes, R., \& López-Sabater, M. C. (2014). Vitamins, fatty acids, and antioxidant capacity stability during storage of freezedried human milk. International journal of food sciences and nutrition, 65(6), 703-707.

Lu, J., Wang, X., Zhang, W., Liu, L., Pang, X., Zhang, S., \& Lv, J. (2016). Comparative proteomics of milk fat globule membrane in different species reveals variations in lactation and nutrition. Food chemistry, 196, 665-672.

Lu, J., Zhang, S., Liu, L., Pang, X., Ma, C., Jiang, S., \& Lv, J. (2018). Comparative proteomics analysis of human and ruminant milk serum reveals variation in protection and nutrition. Food chemistry, 261, 274-282.

Ma, Y., Zhang, L., Wu, Y., \& Zhou, P. (2019). Changes in milk fat globule membrane proteome after pasteurization in human, bovine and caprine species. Food chemistry, 279, 209-215.

Maia, P. R. D. S., Almeida, J. A. G. D., Novak, F. R., \& Silva, D. A. D. (2006). Rede Nacional de Bancos de Leite Humano: gênese e evolução.

Malafronte, L., Ahrné, L., Innings, F., Jongsma, A., \& Rasmuson, A. (2015). Prediction of regions of coalescence and agglomeration along a spray dryerapplication to skim milk powder. Chemical engineering research and design, 104, 703-712.

Malinowska-Pańczyk, E., Królik, K., Skorupska, K., Puta, M., Martysiak-Żurowska, D., \& Kiełbratowska, B. (2019). Microwave heat treatment application to pasteurization of human milk. Innovative Food Science \& Emerging Technologies, 52, $42-48$.

Manin, L. P., Rydlewski, A. A., Galuch, M. B., Pizzo, J. S., Zappielo, C. D., Senes, C. E., \& Visentainer, J. V. (2019). Evaluation of the Lipid Quality of Lyophilized Pasteurized Human Milk for Six Months by GC-FID and ESI-MS. Journal of the Brazilian Chemical Society, 30(8), $1579-1586$.

Martin, N. H., Boor, K. J., \& Wiedmann, M. (2018). Symposium review: Effect of post-pasteurization contamination on fluid milk quality. Journal of dairy science, 101(1), 861-870.

Matak, K. E., Sumner, S. S., Duncan, S. E., Hovingh, E., Worobo, R. W., Hackney, C. R., \& Pierson, M. D. (2007). Effects of ultraviolet irradiation on chemical and sensory properties of goat milk. Journal of dairy science, 90(7), 3178-3186.

Mateos-Vivas, M., Rodríguez-Gonzalo, E., Domínguez-Álvarez, J., García-Gómez, D., Ramírez-Bernabé, R., \& Carabias- Martínez, R. (2015). Analysis of free nucleotide monophosphates in human milk and effect of pasteurisation or high-pressure processing on their contents by capillary electrophoresis coupled to mass spectrometry. Food chemistry, 174, 348-355.

Mayayo, C., Montserrat, M., Ramos, S. J., Martínez-Lorenzo, M. J., Calvo, M., Sánchez, L., \& Pérez, M. D. (2014). Kinetic parameters for high-pressureinduced denaturation of lactoferrin in human milk. International Dairy Journal, 39(2), 246-252.

Meneses, T. M. X. D., Oliveira, M. I. C. D., \& Boccolini, C. S. (2017). Prevalence and factors associated with breast milk donation in banks that receive human milk in primary health care units. Jornal de pediatria, 93(4), 382-388.

Menon, A., Stojceska, V., \& Tassou, S. (2020). A systematic review on the recent advances of the energy efficiency improvements in non-conventional food drying technologies. Trends in Food Science \& Technology.

Mitsue, S. C. (2010). Perfil sócio-econômico e ambiental de doadoras de um Banco de Leite Humano no Vale do Paraíba, SP e a qualidade sanitária do leite ordenhado.

Moltó-Puigmartí, C., Permanyer, M., Castellote, A. I., \& López-Sabater, M. C. (2011). Effects of pasteurisation and high-pressure processing on vitamin C, tocopherols and fatty acids in mature human milk. Food Chemistry, 124(3), 697-702.

Mujumdar, A. S., Huang, L. X., \& Chen, X. D. (2010). An overview of the recent advances in spray-drying. Dairy Science \& Technology, 90(2), $211-224$.

Nebbia, S., Giribaldi, M., Cavallarin, L., Bertino, E., Coscia, A., Briard-Bion, V., \& Deglaire, A. (2020). Differential impact of Holder and High Temperature Short Time pasteurization on the dynamic in vitro digestion of human milk in a preterm newborn model. Food Chemistry, 127126.

O'Sullivan, J. J., Norwood, E. A., O'Mahony, J. A., \& Kelly, A. L. (2019). Atomisation technologies used in spray drying in the dairy industry: A review. Journal of food engineering, 243, 57-69.

Ozmen, L., \& Langrish, T. A. G. (2003). An experimental investigation of the wall deposition of milk powder in a pilot-scale spray dryer. Drying technology, 21(7), 1253-1272.

Panchal, H., Patel, R., Chaudhary, S., Patel, D. K., Sathyamurthy, R., \& Arunkumar, T. (2018). Solar energy utilisation for milk pasteurisation: A comprehensive review. Renewable and Sustainable Energy Reviews, 92, 1-8.

Parikh, D. M. (2015). Vacuum drying: basics and application. Chem Eng, 122(4), 48-54. 
Parrón, J. A., Ripollés, D., Ramos, S. J., Pérez, M. D., Calvo, M., \& Sánchez, L. (2018). Effect of thermal and high-pressure treatments on the antirotaviral activity of human milk fractions. Innovative Food Science \& Emerging Technologies, 47, 262-270.

Passarini, J., Canata, A. P. R., Zago, K. B. A., Tirapeli, K. G., Medrado, M. M. P. M., da Costa, L. G., \& Oliveira, J. (2017). OPGr o53-Taxa de descarte de leite humano e fatores relacionados. Archives Of Health Investigation, 6., v. 6, 2017.

Path - Program for Appropriate Technology in Health. Strengthening human milk banking: A global implementation framework. Version 1. Bill \& Melinda Gates Foundation Grand Challenges Initiative, Seattle, WA. 2013.

Peila, C., Moro, G. E., Bertino, E., Cavallarin, L., Giribaldi, M., Giuliani, F., \& Coscia, A. (2016). The effect of holder pasteurization on nutrients and biologically-active components in donor human milk: a review. Nutrients, 8(8), 477.

Peixoto, R. R. A., Fernández-Menéndez, S., Fernández-Colomer, B., Vaquero, A. I. P., Cadore, S., Sanz-Medel, A., \& Fernández-Sánchez, M. L. (2020). Impact of Holder pasteurization on essential elements from human donor milk: Total contents and protein-binding profiles. Journal of Food Composition and Analysis, 87, 103395.

Percy, S.R. Improvement in drying and concentrating of liquid substances by atomizing. U.S. Patent 125,406, 1872.

Pereira, A. S., Shitsuka, D. M., Pereira, F. J., \& Shitsuka, R. (2018). Metodologia da pesquisa científica. UFSM. https://repositorio.ufsm.br/bitstrea m/handle/1/158 24/Lic_Computacao_Metodologia-Pesquisa-Cientifica.pdf?sequence=1.

Permanyer, M., Castellote, C., Ramírez-Santana, C., Audí, C., Pérez-Cano, F. J., Castell, M., \& Franch, A. (2010). Maintenance of breast milk immunoglobulin A after high-pressure processing. Journal of dairy science, 93(3), 877-883.

Picaud, J. C., \& Buffin, R. (2017). Human milk-treatment and quality of banked human milk. Clinics in Perinatology, 44(1), 95-119.

Picciano, M. F. (1998). Human milk: nutritional aspects of a dynamic food. Neonatology, 74(2), 84-93.

Pisano, R., Arsiccio, A., Capozzi, L. C., \& Trout, B. L. (2019). Achieving continuous manufacturing in lyophilization: Technologies and approaches. European Journal of Pharmaceutics and Biopharmaceutics, 142, 265-279.

Pitino, M. A., Unger, S., Doyen, A., Pouliot, Y., Aufreiter, S., Stone, D., \& O'Connor, D. L. (2019). High hydrostatic pressure processing better preserves the nutrient and bioactive compound composition of human donor milk. The Journal of Nutrition, 149(3), 497-504.

Prachayawarakorn, S., Soponronnarit, S., Wetchacama, S., \& Jaisut, D. (2002). Desorption isotherms and drying characteristics of shrimp in superheated steam and hot air. Drying technology, 20(3), 669-684.

Pronyk, C., Cenkowski, S., \& Muir, W. E. (2010). Drying kinetics of instant Asian noodles processed in superheated steam. Drying Technology, 28(2), 304314.

Rankin, S. A., Bradley, R. L., Miller, G., \& Mildenhall, K. B. (2017). A 100-Year Review: A century of dairy processing advancements-Pasteurization, cleaning and sanitation, and sanitary equipment design. Journal of dairy science, 100(12), 9903-9915.

Ratti, C. (2001). Hot air and freeze-drying of high-value foods: a review. Journal of food engineering, 49(4), 311-319.

Rede Brasileira de Banco de Leite (2019). 〈http://www.redeblh.fiocruz.br/cgi/cgilua.exe/sys/start.htm?sid=360>

Rocha-Pimienta, J., Martillanes, S., Ramírez, R., Garcia-Parra, J., \& Delgado-Adamez, J. (2020). Bacillus cereus spores and Staphylococcus aureus sub. aureus vegetative cells inactivation in human milk by high-pressure processing. Food Control, 107212.

Romeu-Nadal, M., Castellote, A. I., Gayà, A., \& López-Sabater, M. C. (2008). Effect of pasteurisation on ascorbic acid, dehydroascorbic acid, tocopherols and fatty acids in pooled mature human milk. Food chemistry, 107(1), 434-438.

Rosa, E. D., Tsukada, M., \& Freitas, L. A. P. (2006). Secagem por atomização na indústria alimentícia: fundamentos e aplicações. Jornada Científica da Fazu/Faculdades Associadas de Uberaba, 5.

Rydlewski, A. A., Pizzo, J. S., Manin, L. P., Zappielo, C. D., Galuch, M. B., Santos, O. O., \& Visentainer, J. V. (2020). Métodos analíticos utilizados para a determinação de lipídios em leite humano: uma revisão. Revista Virtual de Química, 12(1).

Shama, G. (1999). Ultraviolet light.

Shishir, M. R. I., \& Chen, W. (2017). Trends of spray drying: A critical review on drying of fruit and vegetable juices. Trends in food science \& technology, 65, 49-67.

Siacor, F. D. C., Lim, K. J. A., Cabajar, A. A., Lobarbio, C. F. Y., Lacks, D. J., \& Taboada, E. B. (2020). Physicochemical properties of spray-dried mango phenolic compounds extracts. Journal of Agriculture and Food Research, 100048.

Silva, C. R. D., Martins, E., Silveira, A. C. P., Simeão, M., Mendes, A. L., Perrone, Í. T., \& de Carvalho, A. F. (2017). Thermodynamic characterization of single-stage spray dryers: Mass and energy balances for milk drying. Drying Technology, 35(15), 1791-1798.

Silva, R. C. D., Escobedo, J. P., Gioielli, L. A., Quintal, V. S., Ibidi, S. M., \& Albuquerque, E. M. (2007). Composição centesimal do leite humano e caracterização das propriedades físico-químicas de sua gordura. Química Nova, 30(7), 1535-1538.

Silveira, T. M. L., Fonseca, L. M., Cançado, S. V., \& Ferraz, V. (2004). Comparação entre os métodos de referência e a análise eletrônica na determinação da composição do leite bovino. Arquivo Brasileiro de Medicina Veterinária e Zootecnia, 56(6), 782-787. 
Research, Society and Development, v. 10, n. 12, e106101220118, 2021

(CC BY 4.0) | ISSN 2525-3409 | DOI: http://dx.doi.org/10.33448/rsd-v10i12.20118

Silvestre, D., Miranda, M., Muriach, M., Almansa, I., Jareño, E., \& Romero, F. J. (2010). Frozen breast milk at-20 C and-80 C: A longitudinal study of glutathione peroxidase activity and malondialdehyde concentration. Journal of Human Lactation, 26(1), 35-41.

Sinanoglou, V. J., Cavouras, D., Boutsikou, T., Briana, D. D., Lantzouraki, D. Z., Paliatsiou, S., \& Zoumpoulakis, P. (2017). Factors affecting human colostrum fatty acid profile: A case study. PLoS One, 12(4), e0175817.

Smith, T. J., Campbell, R. E., \& Drake, M. A. (2016). Sensory properties of milk protein ingredients. In Advanced Dairy Chemistry (pp. 197-223). Springer, New York, NY.

Sousa, S. G., Delgadillo, I., \& Saraiva, J. A. (2016). Human milk composition and preservation: evaluation of high-pressure processing as a nonthermal pasteurization technology. Critical reviews in food science and nutrition, 56(6), 1043-1060.

Spatz, D. L. (2018). Pasteurized donor human milk and milk banking through the Human Milk Banking Association of North America. Journal of Obstetric, Gynecologic \& Neonatal Nursing, 47(4), 545-546.

Speckhahn, A., Srzednicki, G., \& Desai, D. K. (2010). Drying of beef in superheated steam. Drying Technology, 28(9), $1072-1082$.

Terpstra, F. G., Rechtman, D. J., Lee, M. L., Hoeij, K. V., Berg, H., Engelenberg, F. A. V., \& Wout, A. B. V. T. (2007). Antimicrobial and antiviral effect of high-temperature short-time (HTST) pasteurization applied to human milk. Breastfeeding Medicine, 2(1), 27-33.

Tran, M. T. T., \& Farid, M. (2004). Ultraviolet treatment of orange juice. Innovative Food Science \& Emerging Technologies, 5(4), 495-502.

Viazis, S., Farkas, B. E., \& Allen, J. C. (2007). Effects of high-pressure processing on immunoglobulin A and lysozyme activity in human milk. Journal of human Lactation, 23(3), 253-261.

Viazis, S., Farkas, B. E., \& Jaykus, L. A. (2008). Inactivation of bacterial pathogens in human milk by high-pressure processing. Journal of food protection, $71(1), 109-118$.

Vincenzetti, S., Cecchi, T., Perinelli, D. R., Pucciarelli, S., Polzonetti, V., Bonacucina, G., \& Vallesi, P. (2018). Effects of freeze-drying and spray-drying on donkey milk volatile compounds and whey proteins stability. $L W T, 88,189-195$.

Vincenzetti, S., Savini, M., Cecchini, C., Micozzi, D., Carpi, F., Vita, A., \& Polidori, P. (2011). Effects of lyophilization and use of probiotics on donkey's milk nutritional characteristics. International Journal of Food Engineering, 7(5).

Visentainer, J. V., Santos, O. O., Maldaner, L., Zappielo, C., Neia, V., Visentainer, L., \& Galuch, M. (2018). Lipids and Fatty Acids in Human Milk: Benefits and Analysis. Biochemistry and Health Benefits of Fatty Acids.

Vishali, D. A., Monisha, J., Sivakamasundari, S. K., Moses, J. A., \& Anandharamakrishnan, C. (2019). Spray freeze drying: Emerging applications in drug delivery. Journal of Controlled Release, 300, 93-101.

Zhu, D., Kebede, B., Chen, G., McComb, K., \& Frew, R. (2020). Impact of freeze-drying and subsequent storage on milk metabolites based on 1H NMR and UHPLC-QToF/MS. Food Control, 116, 107017

Ziaee, A., Albadarin, A. B., Padrela, L., Femmer, T., O'Reilly, E., \& Walker, G. (2019). Spray drying of pharmaceuticals and biopharmaceuticals: Critical parameters and experimental process optimization approaches. European Journal of Pharmaceutical Sciences, 127, 300-318. 